\title{
Reality Therapy untuk meningkatkan penyesuaian diri remaja dengan gangguan major depressive disorder
}

$\Phi$ PROCEDIA Studi Kasus dan Intervensi Psikologi p-ISSN 2302-1462; e-ISSN 2722-7669 ejournal.umm.ac.id/index.php/procedia 2021, Vol 9(2):62-66

DOI:10.22219/procedia.v9i2.16318

(c) The Author(s) 2021

(i)(\$) 4.0 International license

\author{
Intan Novantin Citra Ady ${ }^{1}$
}

\begin{abstract}
The subject is an 18-year-old prisoner who was diagnosed with Major Depressive Disorder. The assessments used include interviews, observations, WARTEGG tests, SSCT tests, and Graphic tests. The results of the assessment show that the subject is a person who is difficult to adjust to a new environment, cannot accept his current life and wants to commit suicide. The intervention given was Reality Therapy which consisted of seven sessions. The purpose of this intervention is to help the subject to realize his own needs and make the right decisions for him. The results of the intervention showed that the subject became more accepting of his life in prison and could more calmly carry out activities in prison.
\end{abstract}

\section{Keywords}

Depression, adjustment, youth in prison, Reality Therapy

\section{Pendahuluan}

Major Depressive Disorder (MDD) merupakan sindrom yang ditandai dengan perasaan tertekan atau hilangnya ketertarikan atau perasaan senang dalam kebanyakan aktivitas. Gejala lainnya berupa perasaan tidak berharga atau bersalah, gagasan untuk bunuh diri, percobaan bunuh diri, agitasi psikomotor atau kelambanan psikomotor, insomnia atau hypersomnia, penurunan atau peningkatan berat badan, terganggunya konsentrasi, kesulitan berpikir, dan kehilangan tenaga (American Psychiatry Association, 2013).

Masalah penyesuaian diri terjadi pada subjek dimana dirinya seringkali menangis dan absen kegiatan binker yang telah ia ikuti yang mengakibatkan produksi melambat karena dirinya tidak datang bekerja. Rencana intervensi yang digunakan dalam penanganan kasus ini yakni menggunakan terapi realitas, dimana terapi ini membantu dalam mengubah pikiran dan perilaku individu untuk mengembangkan kehidupan lebih efisien, dengan memberikan hasil jangka pendek dan dapat diterapkan pada problem yang luas (Odacı \& Çelik, 2017). Terapi realitas didasarkan pada Choice Theory, dasar teoritis untuk terapi realitas; untuk menjelaskan mengapa dan bagaimana kita berfungsi. Terapi realitas memberi cara untuk mengatasi dan membantu individu mengambil kendali yang lebih efektif terhadap kehidupan mereka. Jika Choice Theory adalah jalan raya, Terapi realitas adalah kendaraan yang mengantarkan produk. Terapi ini bertujuan membantu dan mengajar subjek untuk membuat pilihan yang lebih efektif ketika mereka berurusan dengan orang yang mereka butuhkan dalam hidup mereka. Glasser (2004) berpendapat bahwa sangat penting bagi terapis untuk membangun hubungan yang memuaskan dengan subjek sebagai prasyarat untuk terapi yang efektif. Setelah hubungan ini dikembangkan, keterampilan terapis sebagai guru mengambil peran sentral.

Terapi realitas telah digunakan dalam berbagai bentuk pengaturan. Terapis Terapi realitas percaya bahwa masalah yang mendasari kebanyakan subjek merupakan hal yang sama: mereka terlibat dalam hubungan yang tidak memuaskan saat ini atau kurang memiliki hubungan atau tidak sama sekali dengan orang lain. Banyak masalah subjek disebabkan oleh ketidakmampuan mereka untuk terhubung, untuk menjadi dekat dengan orang lain, atau untuk memiliki hubungan yang memuaskan atau sukses dengan setidaknya satu orang yang penting dalam hidup mereka. Terapis membimbing subjek menuju hubungan yang memuaskan dan mengajarkan mereka cara berperilaku yang lebih efektif. Semakin banyak subjek dapat terhubung dengan orang, semakin besar peluang mereka untuk mengalami kebahagiaan. Glasser (2004) menekankan bahwa individu harus berperilaku dengan bertanggungjawab sehingga mereka tidak mengganggu orang lain dalam memenuhi kebutuhan

\footnotetext{
${ }^{1}$ Universitas Muhammadiyah Malang

Korespondensi:

Intan Novantin Citra Ady, Direktorat Program Pascasarjana, Universitas Muhammadiyah Malang, Jl. Tlogomas 246 Malang, Indonesia Email: intan.nca@gmail.com
} 


\section{Metode Asesmen}

Metode Asesmen yang digunakan dalam kasus ini diantaranya ialah wawancara semi terstruktur yang dilakukan dengan tujuan untuk eksplorasi informasi tentang permasalahan yang saat ini dirasakan oleh Subjek. Wawancara semi terstruktur menggunakan instrumen SRQ (self reporting questionaire) dan RRI yang merupakan instrumen wajib yang harus digunakan di Lapas. Metode yang kedua ialah dengan melakukan observasi sebagai penunjang hasil wawancara. Observasi dilakukan pada saat sesi terapi dimulai, ini bertujuan untuk mengetahu perilaku yang muncul pada masing-masing Subjek pada situasi tertentu selama berjalannya terapi.

Metode selanjutnya ialah pemberian Tes grafis yang bertujuan untuk eksplorasi kepribadian Subjek. Dilakukan juga tes Wartegg dengan tujuan untuk melihat sejauh mana masalah-masalah yang ada meluas dalam diri individu dan melihat bagaimana pola gaya penyelesaian masalah yang dimiliki Subjek. Pemberian adjustmen scale juga dilakukan ada saat pretes dan post tes untuk mengukur sejauh mana intervensi yang dilakukan memiliki dampak bagi kondisi Subjek.

\section{Presentasi Kasus}

Subjek seorang wanita remaja berusia 18 tahun. Subjek merupakan anak tunggal sehingga sangat dimanjakan oleh kedua orang tuanya. Orang tua subjek bekerja di luar kota. Subjek seringkali dikunjungi oleh nenek dan kakeknya seminggu dua kali. Saat ini subjek sedang menjalani masa pidananya terkait perlindungan anak. Sebelum ditangkap subjek hanya bekerja sebagai penjual online shopping dan seorang pelajar.

Kasus yang membawa subjek akhirnya harus mendekam di lapas yaitu dikarenakan dirinya membunuh remaja wanita yang usianya satu tahun lebih muda yang diawali konflik bedak yang subjek jual di online shopnya. Korban merupakan orang yang baru dikenal subjek melalui pacar subjek dimana korban tersebut ternyata menyukai pacar subjek dan ingin membunuh subjek jika subjek tidak memberikan pacarnya pada korban. Subjek awalnya mendapatkan hukuman 20 tahun namun berhasil turun menjadi 14 tahun setelah mengikuti beberapa sidang dan meminta keringanan pada hakim. Selain itu subjek juga pernah akan dibuat lumpuh oleh orang tua korban mengingat korban juga merupakan anak tunggal sama seperti subjek.

Subjek memiliki keluhan untuk menyesuaikan diri dengan kehidupan lapas, masih belum bisa menerima dirinya berada di Lapas, ingin menjadi orang lain, serta beberapa kali berfikiran untuk mengakhiri hidup. Akibat pemikirannya tersebut membuat subjek menjadi tidak nafsu makan, seringkali menangis, kurang bisa mengontrol emosi, dan malas melakukan aktivitas di lapas mengingat masa hukuman subjek sendiri yang sangat lama yaitu 14 tahun sementara dirinya baru menjalani hanya 2 tahun. Berkaitan dengan fenomena ini, pendekatan berbasis realitas yang dikemukakan oleh Glasser (2004) berpandangan bahwa setiap individu yang dilahirkan ke dunia memiliki lima kebutuhan dasar yang harus terpenuhi jika ingin merasa bahagia dalam hidupnya. Lima kebutuhan dasar tersebut yakni kebutuhan untuk bertahan hidup, dicintai, kekuatan, kesenangan dan kebebasan. Adanya ketidak bahagiaan dapat disebabkan karena adanya salah satu atau lebih dari kelima kebutuhan dasar tersebut yang tidak terpenuhi (Corey, 2013). Kebutuhan akan cinta menurut Glasser (2004) merupakan satu kebutuhan yang paling utama dari seorang individu karena sebagai makhluk sosial, untuk memenuhi kebutuhan yang lainnya kita memerlukan orang lain.

Glasser (2004) menunjukkan kita semua terlahir dengan kebutuhan genetik dan kita selalu berperilaku untuk memuaskan satu atau lebih dari kebutuhan ini. Lima kebutuhan dasar yang menurutnya umum bagi manusia adalah bertahan hidup, cinta dan memiliki, kekuatan, kebebasan dan kesenangan. (a) Bertahan hidup, kesehatan, dan reproduksi: ini mencakup semua fungsi fisiologis yang dilakukan oleh tubuh dalam upaya untuk membangun dan mempertahankan kesehatan dan homeostasis (keseimbangan sehat kita). itu juga termasuk dorongan seksual kita yang pada akhirnya memungkinkan spesies kita bertahan hidup. Pada hal ini subjek sudah mempertahankan hidupnya dengan baik tetapi dengan membunuh orang lain sehingga subjek harus menerima hukuman dari perbuatannya tersebut. (b) Cinta dan rasa memiliki: kebutuhan penting yang kita miliki untuk cinta dan persahabatan, untuk berbagi dan bekerja sama. Pada fase ini subjek merasa kurang mendapatkan cinta lagi karena orang tuanya berada di luar kota dan sibuk sekali sehingga jarang mengunjungi bahkan menhubungi subjek sehingga subjek merasa dirinya telah diabaikan. (c) Harga diri / kekuatan: kata lain yang bisa dimasukkan di sini adalah kompetensi, harga diri, pemberdayaan, atau rasa mampu untuk melakukan sesuatu. Saat di lapas tidak banyak yang dapat dilakukan subjek dirinyapun merasa putus asa untuk melanjutkan kuliah. (d) Kebebasan: artinya kemampuan untuk membuat pilihan; untuk bergerak; untuk mandiri; untuk merasa tidak terkendali dan tidak terkekang (termasuk memiliki ruang fisik yang cukup). Di lapas subjek seringkali jengkel karena dimarahi dan diomeli oleh napi lain yang kebanyakan lebih tua darinya sehingga kebebasannya pun lebih berkurang lagi, dirinya terikat oleh peraturan lapas yang sangat padat bahkan hanya boleh menonton tv hanya di hari minggu. (e) Kesenangan dan Kenikmatan: kebutuhan yang dapat mengekspresikan dirinya dalam hampir setiap aktivitas manusia. itu termasuk 'minat' dan permainan yang, menurut Glasser, sangat penting untuk belajar. Pada fase ini subjek terpaksa hanya bisa memilih kegiatan-kegiatan yang disediakan oleh lapas dirinya kurang dapat berkreasi. Hal tersebut yang menjadi penguat dan membuat subjek semakin tertekan mengingat semua 5 dasar kebutuhan 
tidak terpenuhi ditambah hukuman subjek yang paling lama diantara remaja lainnya.

Sebagai seorang narapidana yang telah menjalani hukumannya selama dua tahun terkurung dalam penjara. Terdapat perubahan-perubahan yang sering terjadi mengingat blok subjek disatukan dengan napi yang memiliki anak dalam satu blok sementara napiyang berumur remaja sampai anak-anak seringkali hanya mendapatkan hukuman yang tidak selama yang subjek dapatkan makin membuat subjek stress dengan keadaanya dan semakin sulit menerima hidupnya Dalam hal ini kebutuhan dasar untuk bertahan hidup (survival) akan terasa sulit untuk terpenuhi karena adanya krisis antara ketidasadaran subjek atas kehidupannya dan kenyataan yang subjek harus jalani sebagai konsekuensi atas perilaku yang telah subjek lakukan.

Berdasarkan hasil dari uraian masalah yang muncul pada subjek, sasaran intervensi yang akan dilakukan akan terfokus pada bagaimana cara mereduksi penerimaan subjek untuk menjalani hukuman dari perilakunya tersebut yang dirasakan oleh subjek dengan membuat subjek lebih menyadari bahwa dirinya memiliki kontrol penuh atas apa yang akan ia lakukan untuk menjalani masa depan yang lebih baik sesuai dengan ekspektasinya.

\section{Diagnosis dan Prognosis}

\section{Diagnosis}

Berdasarkan hasil diagnosa menurut DSM-V (Diagnostic and Statistical Manual of Mental Disorder fifth edition) menunjukkan bahwa subjek memenuhi kriteria diagnostik: kode 296.33 (F33.2) Major Depressive Disorder. Subjek mengalami perasaan bersalah, sedih, putus asa, berkurang minat dalam berbagai aktivitas, stres sepanjang hari, perasaan tidak berharga, berkurang kemampuan berpikir setiap hari dan beberapa kali memiliki pikiran untuk melakukan bunuh diri.

Secara umum, taraf keberfungsian subjek dalam 30 hari terakhir menurut WHODAS 2.0 dengan skor total 2,49, yang artinya beberapa aktivitas subjek terganggu, sehingga dapat dikatakan taraf keberfungsian subjek adalah kurang berfungsi dengan baik. Pada taraf keberfungsian dalam pengertian dan komunikasi kurang berfungsi dengan baik $(3,33)$, keberfungsian dalam penguasaan lingkungan berfungsi dengan kurang baik $(2,6)$, keberfungsian pada perawatan diri berfungsi dengan cukup baik $(1,75)$, keberfungsian pada pergaulan berfungsi dengan baik $(1,4)$, keberfungsian pada kegiatan sehari-hari kurang berfungsi dengan baik $(2,5)$, dan keberfungsian pada partisipan masyarakat kurang berfungsi dengan baik (3.4). Secara kesimpulan, subjek memiliki hambatan pada pergaulan sosial dan aktivitas sehari-hari.

\section{Prognosis}

Diperkirakan keberhasilan dari intervensi yang akan diberikan berpengaruh baik. Hal tersebut diperoleh berdasarkan motivasi yang dimiliki subjek cukup besar ketika akan diberikan intervensi. Selain itu, subjek juga cukup kooperatif dalam proses asesmen sehingga hal tersebut dapat menunjang keefektifan dari intervensi yang diberikan hingga proses intervensi berakhir.

\section{Intervensi}

Intervensi yang digunakan dalam kasus ini ialah terapi realitas. Target dalam kasus ini yaitu meningkatkan kesadaran diri subjek untuk menerima kehidupannya di lapas dengan rajin mengikuti kegiatan lapas. Pemberian terapi realita diketahui secara signifikan dapat meningkatkan penyesuaian, emosional, sosial dan pendidikan

Metode WDEP (wants, doing, evaluation, planning) yang digunakan dalam terapi realita akan dilakukan dalam setting individu dimana metode dilakukan untuk membimbing subjek agar menemukan cara yang lebih efektif dalam mengatasi penyesuaian dirinya yang ia rasakan terkait dengan berbagai hal perubahan-perubahan yang akan subjek hadapi pada saat tinggal di lapas hingga masa tahanannya telah usai. Subjek juga diharapkan akan memiliki kontrol yang baik dan lebih efektif atas kehidupannya di masa yang akan datang.

WDEP System merupakan akronim sederhana yang digunakan Glasser. Setiap huruf mewakili sejumlah teknik yang digunakan, bukan dalam set kronologi tahapan, tetapi sebagaimana yang sesuai untuk klien. Keempat bagian dari sistem ini dicapai melalui pertanyaan yang terampil yang membantu klien untuk berpikir.

Wants (W) yaitu mengacu pada keinginan kebutuhan (needs), dan persepsi. Hal ini untuk membantu klien mengidentifikasi dan mendefinisikan keinginan mereka, apa kebutuhan yang terpenuhi atau tidak terpenuhi dan membingkai ulang masalah menjadi tujuan untuk memperjelas persepsi mereka. Mereka juga diminta untuk mengukur tingkat komitmen mereka terhadap keinginankeinginan ini.

Doing (D) yaitu mengacu pada arah, dan tindakan (actions). Pada tahap ini, klien diminta untuk mempertimbangkan apa yang mereka lakukan dan arah keseluruhan yang mereka tuju. Fokusnya di sini adalah pada tindakan dan pikiran, karena kedua komponen inilah yang menjadi kontrol langsung klien. Pada saat yang sama, mereka diminta untuk mempertimbangkan dan melihat gambaran yang lebih besar; itulah yang mereka 'inginkan' untuk kepuasan jangka panjang dari satu atau lebih dari kebutuhan mereka.

Evaluation (E) yaitu mengacu pada evaluasi diri, Ini adalah inti dari Reality Therapy, di mana klien diminta untuk mengevaluasi perilaku mereka saat ini dan apakah perilaku ini menggerakkan mereka ke arah yang mereka inginkan. Ini terjadi ketika klien mulai mengevaluasi perilaku mana yang lebih efektif bagi mereka dalam mendapatkan apa yang mereka inginkan dan perilaku mana yang kurang efektif dalam proses penemuan diri ini. 
Planning (P) mengacu pada perencanaan, yang disebut Dr. Wubbolding sebagai SAMIC 3 / P. Terapis membantu klien dalam membuat rencana yang $S$ (Sederhana), A (Dapat Dicapai), M (Terukur), I (Segera dan Terlibat) dan C (Konsisten, Dikontrol oleh klien, dan Disiapkan oleh klien. Menurut Dr. Wubbolding, rencana yang disusun oleh klien memiliki efek terbaik. Waktu maksimum dikhususkan untuk tahap sistem ini. Klien didorong untuk membangun beberapa perilaku yang lebih efektif yang ia dapat lakukan, dan dia mencari lebih banyak melalui proses evaluasi diri.

Sesi 1: Membangun raport dan kontrak kerja. Terapis menjalin raport dan memperkenalkan program konseling yang akan dilakukan serta menjelaskan aturan-aturan, yaitu terapis mendorong subjek untuk lebih terbuka, menjamin kerahasiaan dalam terapi dan diskusi bersama. Dilanjutkan dengan pemberian skala penyesuaian diri sebagai pretest. Pada sesi ini subjek dan terapis memperkenalkan dirinya. Sesi ini berjalan lancar, seru dan tanpa malu-malu. Saat diberikan penjelasan tentang aturan pelaksaan terapi subjek memahaminya dengan baik. Hasil skala penyesuaian diri yang diberikan menunjukkan bahwa subjek memiliki penyesuaian diri dalam kategori sedang.

Sesi 2: Eksplorasi keinginan, kebutuhan dan persepsi (Wants). Pada sesi ini terapis menjelaskan secara verbal tentang adanya Quality of World dan Basic needs pada subjek. Selanjutnya, subjek mengungkapkan keinginan, kebutuhan dan sejauh mana pemenuhan kebutuhan yang telah diupayakan. Hasil dari sesi yaitu subjek memiliki keinginan terkait mengahadapi kondisi lapas yang tidak tentu, berusaha menghadapi kenyataan bahwa hukuman lapas merupakan resiko perbuatannya.

Sesi 3: Mendiskusikan perilaku total (Doing) Pada sesi ini subjek mendiskusikan perilakunya, bagaimana pikiran perasaan,respon fisik ketika adanya perilaku yang tidak ia sukai dari orang lain. Dalam sesi ini, subjek menceritakan bagaimana dan apa saja yang telah dilakukan dan rasakan selama ini. Kesimpulan pada sesi ini bahwa subjek memiliki respon yang seringkali meresahkan dirinya dalam menghadapi rasa ketidaknyamanannya yakni dengan, tidak makan, tidak bisa tidur, sering menangis atau diam, serta malas beraktivitas.

Sesi 4: Penilaian dan tindakan (Evaluasi). Pada sesi ini subjek memeriksa keinginan dan mengevaluasi perilakunya selama ini. Terapis dalam sesi ini memiliki peran sebagai pengarah dan pendorong bagi subjek untuk mengevaluasi perilakunya supaya memiliki sisi postif di dalam dirinya, apakah evaluasi pikiran sekarang dapat merugikan atau tidak dan apakah yang subjek lakukan dapat membantu dirinya mencapai yang diinginkan. Hasil pada sesi ini subjek dapat mengevaluasi dirinya dengan perilaku yang ia lakukan atas perilaku orang lain.

Sesi 5: Menyusun keinginan dan komitmen bersama (Plan) Terapis dan subjek berupaya menyusun perencanaan terkait dengan bagaimana atau apa saja upaya yang dapat diusahakan untuk mendapatkan apa yang diinginkan (wants) yaitu supaya nantinya lebih siap menghadapi kehidupan lapas sehingga dengan rencana yang matang dapat meningkatkan penyesuaian dirinya saat ini dan percaya atas kemampuan dalam dirinya. Target pada sesi ini ialah subjek dapat membuat strategi dengan membuat rencana dan menentukan tindakan yang realistis. Subjek diharapkan memiliki tujuan yaitu dapat menyesuaikan diri dan menerima bahwa dirinya harus menjalani hukuman.

Sesi 6: Evaluasi dan Terminasi Terapis melakukan evaluasi terhadap planning yang telah subjek rencanakan dengan menanyakan kesulitan dan hambatan yang dialami. Kemudian subjek diminta untuk mengungkapkan perasaannya setelah menjalankan sesi terapi dan diakhiri dengan pemberian post-test adjustment scale untuk mengukur adanya perubahan tingkat penyesuaian diri dari subjek setelah melakukan seluruh rangkaian terapi.

Sesi 7: Follow Up Follow Up dilakukan dua minggu setelah terminasi untuk mengetahui apakah terjadi perbaikan kondisi dan penurunan simtom penyesuaian diri dari subjek. Follow Up dilakukan dengan pertemuan dan perbincangan langsung dengan subjek. Subjek beserta terapis membicarakan tentang perasaan yang dirasakan setelah sesi terapi selesai. Apakah subjek mengalami peningkatan penyesuaian dan apakah subjek merasa lebih baik dibandingkan kondisi sebelumnya. Pemberian adjustmen scale juga dilakukan pada sesi ini untuk melihat apakah hasil dari intervensi yang dilakukan dapat efektif untuk jangka panjang dan apakah ada faktor penghambat yang dialami oleh subjek. Hasil dari sesi ini ialah Subjek merasa dirinya sudah lebih tenang dan memiliki bayangan yang terarah tentang apa yang harus dilakukan. Selain itu subjek juga mengaku bahwa ketidaknyamanannya lebih bisa terkontrol karena subjek menyadari bahwa perbuatan yang dilakukannya memang salah dan perlu untuk menerima konsekuensinya.

\section{Hasil dan Pembahasan}

\section{Hasil}

Berdasarkan hasil intervensi dapat diketahui subjek mengalami peningkatan tingkat penyesuaian dari sebelum dilakukannya intervensi (pre-test) dibandingkan dengan setelah dilakukkannya intervensi (post-test) dan follow up.

Peningkatan tingkat penyesuaian yang dialami oleh subjek sejalan dengan hasil perubahan yang terjadi pada proses terapi yang diperkuat dengan hasil wawancara pada subjek terkait dengan berkurangnya gejala-gejala ketidaknyamanan yang dirasakan. Subjek telah melengkapi tahapan terapi realitas, dan saat ini derajat ketidaknyamanann yang dirasakan subjek sudah berkurang.

Selain dapat lebih mengenal kekurangan dan kelebihan dirinya, metode WDEP yang dilaksanakan dalam terapi ini juga mengahasilkan rencana tindakan yang dapat dilakukan secara realistis oleh subjek. Rencana tindakan 
yang telah didiskusikan bersama subjek merasa lebih memiliki persiapan yang matang untuk bertahan dan menikmati kegiataan serta menerima kehidupannya di lapas. Selain itu, dengan support yang terjalin pada subjek merasa lebih bisa menerima kenyataan bahwa setiap orang memang memiliki kekurangan dan kelebihan namun sebagai individu kita tetap memiliki kontrol penuh atas apa yang akan menjadi pilihan hidup kita kedepannya.

\section{Pembahasan}

Hasil dari intervensi menunjukkan bahwa Reality Therapy dapat meningkatkan penyesuaian diri yang dirasakan oleh narapidana wanita dalam kehidupannya di dalam lapas. Berdasarkan kasus yang telah diulas diatas, Target perubahan dalam kasus ini telah berhasil dicapai. Hal ini ditunjukkan dengan berkurangnya skor pada adjustment scale yang berarti bahwa terdapat reduksi tingkat ketidaknyamanan yang digambarkan oleh berkurangnya simtom.

Hasil ini juga didukung oleh keterangan dari subjek bahwa pasca menjalani rangkaian sesi intervensi ini subjek merasa bahwa dirinya menjadi lebih siap untuk kembali ke kehidupannya di lapas dengan adanya planing strategi yang telah tersusun, dan kesadaran diri yang meningkat bahwa dirinya memiliki kontrol penuh atas pengambilan keputusan serta tindakan dalam menghadapi hambatan di dalam hidupnya di waktu yang akan datang. Reality Therapy yang dilakukan terbukti efektif untuk mengatasi berbagai masalah individu yang berkaitan dengan persoalan umum dan sulit seperti permasalahan pribadi, sosial, belajar atau akademik, serta karir (Corey, 2013).

Selain itu terapi realitas dapat membantu subjek mengekspresikan dirinya dengan diskusi yang santai, sehingga subjek dapat mendiskusikan cara untuk menghadapi perasaan negatif dan mengontrol apa yang dirasakan (Farmani et al., 2015). Dalam hal ini pemberian intervensi terapi realita yang diterapkan pada subjek pemasyarakatan yang akan segera bebas juga terbukti dapat membantu Subjek pemasyarakatan untuk menghadapi realita kehidupan mereka di masa yang akan datang. Subjek telah memiliki strategi untuk mencapai tujuan yang diinginkan yakni menjalani kehidupan yang lebih baik setelah bebas dari penjara. Adanya strategi yang sudah tersusun secara realistis dapat meningkatkan fokus subjek atas pengembangan dirinya sehingga dapat mengatasi ketidaknyamanannya yang dirasakannya selama ini. Semua target dalam sesi terapi yang dilaksanakan sebanyak tujuh kali tatap muka dengan menggunakan metode WDEP (wants, doing, evaluation, planning) tercapai dan memberikan perkembangan yang positif bagi Subjek.
Rangkaian sesi ini memberikan pemahaman pada diri Subjek bahwa pilihan dan strategi yang telah ia buat akan berdampak pada perilaku dirinya dan orang lain (Nelson, 2015).

\section{Kesimpulan}

Reality therapy dapat membantu meningkatkan penyesuaian diri pada remaja napi lapas yang belum bisa menerima dirinya masuk lapas. Selain itu, Menyusun keinginan dan komitmen sangat membantu subjek untuk berkomitmen pada keinginannya untuk berubah menjadi lebih baik. Melalui terapi realitas, subjek diharapkan dapat mempertahankan penerimaan dirinya masuk lapas sehingga lebih mudah untuk dirinya menyesuaikan diri serta produktif.

\section{Referensi}

American Psychiatry Association. (2013). Diagnostic and statistical manual of mental disorders. Fifth edition. Washington DC: American Psychiatry Association

Odacı, Hatice \& Çelik, Ç Berbe. (2017). The role of traumatic childhood experiences in redicting a disposition to risktaking and aggression in Turkish University students. International Journal of Criminology and Sociological Theory, 35, 9-10. https://doi.org/10.1177/0886260517696862

Corey, G. (2013). Teori dan praktek konseling dan psikoterapi. Yogyakarta : Refika aditama

Dadashazar, N. (2017). Offender recidivism: A quantitative study of motivational risk factors and counseling. Walden University ScholarWorks.

Farmani, F., Taghavi, H., Fatemi, A., \& Safavi, S. (2015). The efficacy of Group Reality Therapy on reducing sress, anxiety and depression in patients wiith multiple sclerosis (MS). International Journal of Applied Behavioral Sciences, 2(4), 33-38. https://doi.org/10.22037/ijabs.v2i4.11421

Gharavi, M. M., Kashani, H., Lotfi, M., \& Borhani, M. (2015). Comparison of depression, anxiety, general mental health and self-esteem Among prisoners in consultancy and ordinary wings. Journal of Fundamentals of Mental Health, 17(1),52-57. http://eprints.mums.ac.ir/3772/ 1/JFMH_Volume\%2017_Issue\%201_Pages\%2052-57.pdf

Glasser, W. (2004). New vision for counseling. The Family Journal: Counseling and Therapy for Couples and Families, 12(4) 339-341. https://doi.org/10.1177/1066480704267486

Karotono, K. (2009). Patologi sosial Jilid I. Raja Grafindo.

Nelson-Jones, R. (2015). Teori dan praktik konseling dan terapi. Pustaka Pelajar

Nevid, S., Rathus, A., \& Greene, B. (2003). Psikologi abnormal (Edisi Kelima Jilid 1). Erlangga. 